\title{
Clinical and echocardiographic predictors of recurrent mitral regurgitation following restrictive mitral annuloplasty. Evaluation in patients with chronic ischemic mitral regurgitation
}

\author{
Witold Streb ${ }^{1}$, Tomasz Niklewski², Dariusz Puszczewicz², Tomasz Kukulski ${ }^{1}$, Roman Przybylski², \\ Jerzy Pacholewicz², Marian Zembala² \\ ${ }^{1}$ Department of Cardiology, Congenital Heart Disease and Electrotherapy, Silesian Center For Heart Diseases, Zabrze \\ 2Department of Cardiosurgery and Transplantology, Silesian Center For Heart Diseases, Zabrze
}

Kardiochirurgia i Torakochirurgia Polska 2013; 10 (2): 99-104

\begin{abstract}
Aim of the study: The aim of this study was to determine the clinical and echocardiographic predictors of recurrent mitral regurgitation after undersized ring implantation for ischemic mitral regurgitation (MR). Recurrent MR occurs in up to 30\% of patients after undersized ring implantation. Understanding the causes of recurrent MR should improve the results of this kind of surgery.

Material and methods: The pre- and postoperative echocardiograms of 134 patients operated on for ischemic mitral regurgitation using ring implantation were analyzed. The median follow-up period was 13 months.

Results: The strongest influence on MR recurrence was exerted by coaptation length (OR 0.022; $p=0.001)$, effective regurgitant orifice area (EROA) (OR 1.85; $p<0.002)$, and vena contracta measured preoperatively (OR 1.42; $p=0.007$ ). The independent predictors of recurrent $M R$ included: the postoperative length of leaflet coaptation, preoperative left ventricular ejection fraction, the severity of regurgitation, and body surface area (BSA). The coaptation length cut-off value of $<6.2 \mathrm{~mm}$ was associated with $94 \%$ sensitivity and $85 \%$ specificity in the prediction of recurrent MR.

Conclusions: This study showed that the recurrence of MR after undersized mitral ring implantation is low. The measure of coaptation length is superior to other echocardiographic parameters in the prediction of MR recurrence. Our model of risk stratification may predict mitral valve repair failure after restrictive annuloplasty.

Key words: restrictive mitral annuloplasty, ischemic mitral regurgitation, echocardiography, predictors.
\end{abstract}

\section{Streszczenie}

Wstęp: Chorobie niedokrwiennej towarzyszy często niedomykalność zastawki mitralnej (MR) w mechanizmie poszerzenia pierścienia lub restrykcji płatków, spowodowana przebudową osłabionego lub uszkodzonego mięśnia lewej komory. Istotna hemodynamicznie niedomykalność wymaga naprawy podczas zabiegów rewaskularyzacji z zastosowaniem pierścieni zwężających. Niestety, zgodnie z danymi z piśmiennictwa do 30\% zastawek ulega powtórnej dysfunkcji z nawrotem istotnej niedomykalności. Przedmiotem badania było określenie klinicznych i echokardiograficznych czynników predykcyjnych nawrotu MR po plastyce zwężającej.

Materiał i metody: Badaną grupę stanowiło 164 kolejnych chorych operowanych z powodu choroby niedokrwiennej serca, u których wykonano rewaskularyzację chirurgiczną oraz plastykę zastawki mitralnej. Analizie poddano przed- i pooperacyjne badania echokardiograficzne oraz badania kontrolne. Średni okres obserwacji wynosił 13 miesięcy.

Wyniki: Nawrót niedomykalności obserwowano u 30 chorych (18,2\%), w tym u 11 (6,7\%) w stopniu średnim i dużym. Najsilniejszy wpływ na nawrót niedomykalności wykazała pooperacyjna długość kooptacji (OR 0,022; $p=0,001)$, przedoperacyjne efektywne pole niedomykalności (ERO) (OR 1,85; $p<0,002)$ oraz wielkość talii niedomykalności (VC) (OR 1,42; $p=0,007)$. Niezależnymi parametrami predykcyjnymi nawrotu MR były pooperacyjna długość kooptacji płatków, wartość przedoperacyjnej frakcji wyrzutowej lewej komory, stopień przedoperacyjnej niedomykalności oraz powierzchnia ciała pacjenta (BSA). Wartość graniczna długości koaptacji wyniosła < 6,2 mm, wykazując 94\% czułości i 85\% specyficzności dla nawrotu MR. Wnioski: Przeprowadzone badanie wykazało niską częstość nawrotu niedomykalności po rewaskularyzacji z jednoczesną plastyką zwężającą niedokrwiennej MR. Wczesny pooperacyjny pomiar długości kooptacji płatków wykazał nadrzędną

\footnotetext{
Address for correspondence: Witold Streb MD, Silesian Center for Heart Disease, Szpitalna 2, 41-800 Zabrze, tel. +48 322713414 , fax +48 323733792 , e-mail: streb@wp.pl
} 


\section{Introduction}

Ischemic heart disease is often complicated by mitral regurgitation (MR). Mitral valve (MV) insufficiency may occur acutely as a complication following acute myocardial infarction (AMI). It may also develop chronically in patients following post-myocardial infarction (MI) LV remodeling, i.e. as functional ischemic mitral regurgitation (FIMR) [1]. The analysis of a large cohort of patients (11 000) with angiographically confirmed significant coronary artery stenoses showed that FIMR was present in about $19 \%$ of them [2] (Fig. 1). There is evidence that MR is a powerful predictor of risk in patients after myocardial infarction. Patients with ischemic MR have higher incidence of cardiovascular mortality ( $29 \%$ vs. $12 \%$ ) and heart failure ( $24 \%$ vs. $16 \%)$ than patients without ischemic MR at a mean of 3.5 years after MI [3]. The presence of ischemic MR was found to be a strong predictor of cardiac events independently of left ventricular systolic and diastolic indexes in patients with ischemic heart disease [4].

The management of ischemic MR remains controversial. The possible therapeutic approaches are: MV replacement with coronary artery revascularization, MV repair with revascularization, or revascularization alone. Significant reduction in MR can be expected in only about $10 \%$ of patients after revascularization alone [5], whereas MV repair or replacement can eliminate or decrease regurgita-

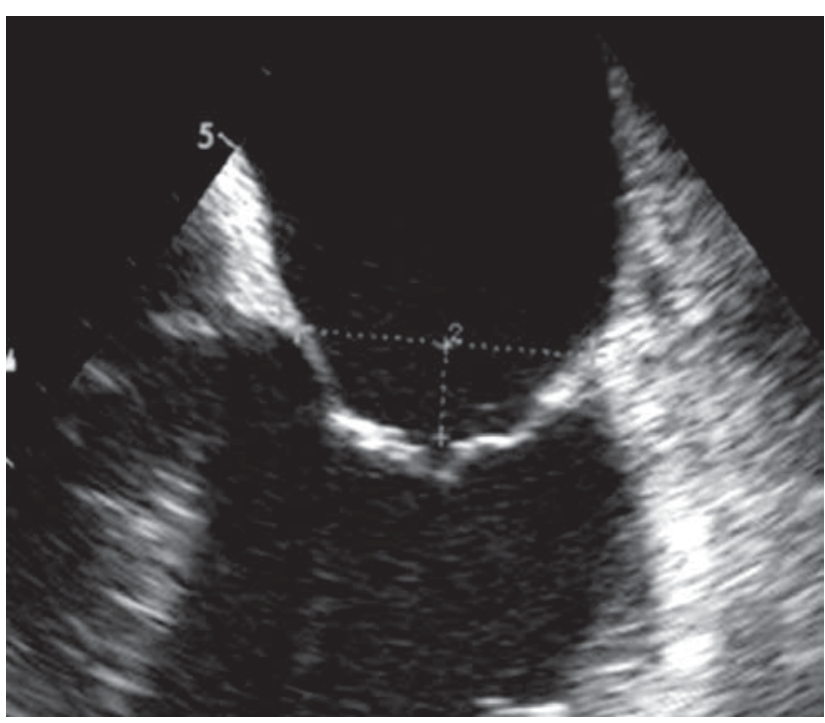

Fig. 1. Restrictive closing of mitral leaflets in transesophageal echo examination (Carpentier type IIIb) w stosunku do innych parametrów wartość predykcyjną nawrotu MR w obserwacji odległej. Przedstawiony model stratyfikacji ryzyka może pozwolić przewidywać nawrót dysfunkcji zastawki po naprawie niedomykalnej zastawki za pomocą plastyki pierścieniowej.

Słowa kluczowe: niedokrwienna niedomykalność mitralna, plastyka mitralna, echokardiografia.

tion in most cases. Although the meta-analysis conducted by Shuhaiber and Anderson of clinical outcomes following surgical MV repair or replacement did not reveal any significant differences in total survival, especially MV repair is associated with lower 30-day mortality due to lower rates of thromboembolism, infections, and the risk of future reoperation [6].

The standard surgical repair consists in undersized annuloplasty, resulting in a decrease in mitral annulus diameter and, thus, in an increase of leaflet coaptation [7]. However, it is reported that, despite adequate patient selection and standard surgical operative techniques, up to $7-30 \%$ of patients after mitral annuloplasty exhibit recurrent MR $[8,9]$. The prediction of recurrent MR after MV repair may guide clinicians when making decisions concerning qualifying patients for mitral repair or replacement. The aim of this study was to determine the clinical and echocardiographic predictors of recurrent MR after restrictive mitral annuloplasty (RMA) and to create a model for risk stratification in patients operated on for ischemic MR.

\section{Material and methods \\ Patients}

The analyzed group consisted of 165 consecutive patients (100 men and 65 women) at the mean age of $64.3 \pm 7.7$ years from a series of 336 patients operated on for ischemic heart disease and moderate to severe MR in the Silesian Center for Heart Diseases in Zabrze. Based on echocardiographic and surgical findings, only the patients with ischemic MR were included into the study. Cases with mitral insufficiency due to other pathologies (e.g. rheumatic, infectious or myxomatous) were excluded. All patients underwent surgical heart revascularization and successful MV repair with undersized ring implantation.

The patients' risk associated with cardiac surgery was calculated based on EuroSCORE and ranged from 1 to 17 with a median of $6.6 \pm 2.5$. 85.4\% of patients had sinus rhythm. Mean body mass index (BMI) and BSA were 27.1 \pm 4.2 and $1.86 \pm 0.45$. Co-morbidities of the study population included diabetes (41.2\%), chronic AF (14.6\%), hypertension (80\%), hyperlipidemia (89.1\%), and peripheral vascular disease $(60.2 \%)$

$90.3 \%$ of patients had a history of previous MI. The inferior wall was the most common wall to be affected by infarction [111 patients (67.3\%), lateral wall $40.1 \%$ and anterior wall $31.5 \%$ ]. The majority of patients (57.5\%) suffered 
from three-vessel disease, $29.1 \%$ from two-vessel disease, and a significant narrowing of a single coronary artery was present in $12.7 \%$ of the study population.

105 patients (63.6\%) had left ventricular ejection fraction (LVEF) (measured in transthoracic echo with the Simpson formula) between 30 and 50\%, 34 (20.6\%) had LVEF above $50 \%$, and 26 (15.8\%) had it lower than $30 \%$.

\section{Echocardiographic study}

All patients underwent transthoracic echocardiographic evaluation prior to cardiac surgery, 5-10 days after the operation, and 8 to 21 months thereafter (median follow-up was 13 months). During the cardiac surgery, transesophageal echocardiography was performed to assess the results of the annuloplasty. Transthoracic examinations were performed with GE VIVID 5 and 9 ultrasound systems with $2.5 \mathrm{MHz}$ transducers, and they were stored digitally. Echocardiographic assessment was performed in standard views by two experienced echocardiographers, in accordance with the recommendations of the American Association of Echocardiography.

The dimensions of the heart chambers were measured in parasternal long axis view in M-mode. Real-time 2D images in two- and four-chamber views were acquired for the assessment of the MV regurgitation mechanism and for the estimation of left ventricular volumes, dimensions, and contractility. The mechanism of MR was categorized according to the Carpentier classification. Only patients with type I or IIIb were included in the study.

The severity of MR was evaluated based on the following quantitative Doppler-derived parameters: effective regurgitant orifice area (EROA) and regurgitant volume. 73 patients (44.2\%) presented moderate, and 92 (55.8\%) severe preoperative MR. Carpentier type I was demonstrated by 74 (44.8\%) and type IIIb by 91 study patients (55.2\%).

\section{Surgical procedure}

The ischemic etiology of MR was confirmed by visual inspection of the mitral leaflets, annulus, chordae tendineae, and papillary muscles during cardiac surgery. If the mitral leaflets and the chordae appeared normal but there were signs of ischemia or infarction involving papillary muscles or signs of mitral annulus dilatation due to post-MI LV dilatation, then the ischemic etiology of regurgitation was concluded. Ischemic MR was repaired by undersized ring annuloplasty. Carpentier-Edwards classic ring implantation was performed in 79 patients (47.9\%). 83 patients (50.3\%) were implanted with Carpentier-Edwards physio rings, 1 patient (0.6\%) was implanted with a Carpentier MC-A ETlogix, and the remaining $2(1.2 \%)$ received Duran rings. The ring size varied from 24 to 32 . In 157 patients, the ring size did not exceed 28; 113 patients (68.5\%) received size 26 rings.

Beside the mitral annuloplasty, $92.1 \%$ of patients had a coronary artery bypass grafting procedure. 29 patients (17.6\%) underwent concurrent repair of the tricuspid valve, 4 patients aortic valve repair, and surgical ablation for atrial fibrillation was performed in 14 subjects.

\section{Postoperative follow-up}

All patients were followed up with transthoracic echocardiographic examination. Median follow-up was 13 months (it varied from 8 to 21 months).

\section{Statistical analysis}

The results are presented as mean and standard deviation. Logistic regression was used for univariate and multivariate analysis of continuous variables. Specificity and sensitivity were calculated based on ROC analysis.

\section{Results}

The comparison of mitral valve regurgitation prior to $M V$ repair and after the follow-up period (mean of 13 months, 8-21), as examined by transthoracic echocardiography, showed that the good results of the operation are long lasting. In the study population, the mean MR, qualitatively categorized to one of four classes, was $3.46 \pm 0.5$ preoperatively, whereas after the observation period it was $0.98 \pm 1.39(p<0.001)$. Significant regurgitation recurred in 30 patients (18.2\%): severe in 11 cases $(6.7 \%)$ and moderate in 19 (11.5\%). Furthermore, the coaptation length, which is one of the predictors of successful MV repair, was significantly greater in the early postoperative period than before the operation ( $0.72 \pm 0.2 \mathrm{~cm}$ vs. $0.21 \pm 0.09 \mathrm{~cm}, p<0.001)$; this effect was sustained over the follow-up $(0.68 \pm 0.2 \mathrm{~cm}$; $p<0.001)$. However, mitral annuloplasty did not influence coaptation depth $(0.62 \pm 0.23 \mathrm{~cm}$ preoperatively vs. $0.63 \pm 0.22 \mathrm{~cm}$ postoperatively).

The positive long-term effect of MV repair was also reflected by the quantitative echocardiographic parameters of MR. Preoperatively, the EROA and regurgitant volume were, respectively, $0.44 \pm 0.16 \mathrm{~cm}^{2}$ and $57 \pm 25.3 \mathrm{ml}$, whereas in follow-up these parameters were significantly reduced (EROA: $0.28 \pm 15 \mathrm{~cm}^{2} ; p<0.001$ and regurgitant volume: $38 \pm 21.6 \mathrm{ml} ; p<0.001)$.

The assessment of left ventricular (LV) function and geometry seems to be as important as the assessment of MR itself in patients treated with surgical annuloplasty. Both global and regional LV remodeling is a causative factor for MV insufficiency, and, thus, it may potentially influence MR recurrence. In our study, no significant changes were found in either systolic or diastolic dimensions and volumes, either before the operation or postoperatively (Table I).

However, the follow-up echocardiographic assessment revealed significant changes in LV geometry, as the systolic and diastolic indexes were reduced significantly after the operation, indicating favorable global remodeling after MV surgery (Table II).

The univariate analysis showed that a number of factors have an influence on the recurrence of MR in long observation. As presented in Tables III and IV, the preoperative echocardiographic parameters dominate over the clinical and perioperative predictors.

The strongest predictor was the coaptation length measured directly after mitral ring implantation (OR 0.0022; 
Clinical and echocardiographic predictors of recurrent mitral regurgitation following restrictive mitral annuloplasty...

Tab. I. Pre- and postoperative echocardiographic assessment of heart chambers

\begin{tabular}{lccc} 
& Preoperatively & Follow-up & $\begin{array}{c}\text { Significance } \\
\text { level } P\end{array}$ \\
LV EDd $(\mathrm{cm})$ & $61.5 \pm 7.0$ & $62.4 \pm 8.5$ & $\mathrm{NS}$ \\
\hline LV ESd $(\mathrm{cm})$ & $46.5 \pm 8.6$ & $46.7 \pm 9.5$ & $\mathrm{NS}$ \\
\hline LV EDV $(\mathrm{ml})$ & $150.6 \pm 47.5$ & $145.2 \pm 49.6$ & $\mathrm{NS}$ \\
\hline LV ESV $(\mathrm{ml})$ & $92.2 \pm 41.8$ & $93.6 \pm 43.8$ & $\mathrm{NS}$ \\
\hline LV EDVI $\left(\mathrm{ml} / \mathrm{m}^{2}\right)$ & $80.4 \pm 23.8$ & $77.4 \pm 24.6$ & $\mathrm{NS}$ \\
\hline LV ESVI $\left(\mathrm{ml} / \mathrm{m}^{2}\right)$ & $49.3 \pm 23.8$ & $50.0 \pm 22.7$ & $\mathrm{NS}$ \\
\hline LVEF $(\%)$ & $39.5 \pm 10.9$ & $38.8 \pm 10.9$ & $\mathrm{NS}$ \\
\hline LAd $(\mathrm{mm})$ & $46.5 \pm 6.6$ & $47.7 \pm 6.7$ & 0.002 \\
\hline RVd $(\mathrm{mm})$ & $51.4 \pm 20.6$ & $38.8 \pm 21$ & $<0.001$ \\
\hline $\begin{array}{l}\text { LV - left ventricle; EDd - end-diastolic dimension; ESd - end-systolic dimension; } \\
\text { EDV - end diastolic volume; ESV - end-systolic volume; EDVI - end-diastolic } \\
\text { volume index; ESVI - end-systolic volume index; LVEF - left ventricular ejection } \\
\text { fraction; LAd - left atrial dimension; RVd - right ventricle dimension }\end{array}$
\end{tabular}

Tab. III. Preoperative risk factors of mitral regurgitation recurrence - univariate analysis

\begin{tabular}{lccc} 
Variable & OR & $95 \%$ CI & $\begin{array}{c}\text { Significance } \\
\text { level } P\end{array}$ \\
length of coaptation & 0.0022 & $0.0001-0.092$ & 0.001 \\
\hline EROA & 1.85 & $1.26-2.72$ & 0.002 \\
\hline vena contracta of MR & 1.42 & $1.1-1.85$ & 0.007 \\
\hline coaptation depth & 1.7 & $0.2-13.7$ & NS \\
\hline degree of MR & 4.7 & $1.5-14.3$ & 0.006 \\
\hline LV EDVI & 1.03 & $1.01-1.05$ & 0.011 \\
\hline LV ESVI & 1.02 & $1.00-1.04$ & NS \\
\hline LV EDd & 1.0 & $0.93-1.07$ & NS \\
\hline LV ESd & 0.98 & $0.93-1.07$ & NS \\
\hline LV EDV & 1.01 & $0.99-1.02$ & NS \\
\hline LV ESV & 1.01 & $0.99-1.02$ & NS \\
\hline LVEF & 0.98 & $0.94-1.03$ & NS \\
\hline LAd & 1.01 & $0.93-1.09$ & NS \\
\hline 4ch diastolic SI bas & 42.5 & $0.04-42867$ & NS \\
\hline 4ch systolic SI bas & 1.02 & $0.01-140$ & NS \\
\hline 4ch diastolic SI med & 207 & $0.45-95583$ & NS \\
\hline 4ch systolic SI med & 22.4 & $0.18-2827$ & NS \\
\hline 2ch diastolic SI bas & 13 & $0.05-4145$ & NS \\
\hline 2ch systolic SI bas & 0.49 & $0.002-141.9$ & NS \\
\hline 2ch diastolic SI med & 36 & $0.1-12611$ & NS \\
\hline 2ch systolic SI med & 26 & $0.23-2872$ & NS \\
\hline RVd & 1.04 & $1.01-1.06$ & 0.003 \\
\hline EROA - effective regurgitant orifice area; MR - mitral regurgitation; LV - left \\
ventricle; EDd - end-diastolic dimension; ESd - end-systolic dimension; EDV- \\
end diastolic volume; ESV - end-systolic volume; EDV - end-diastolic volume \\
index; ESVI - end-systolic volume index; LVEFF - left ventricular ejection fraction; \\
LAd - left atrial dimension; 4ch - four chamber view; 2ch - two chamber view; \\
RVd - right ventricle dimension & & & \\
& & & \\
\hline
\end{tabular}

$p=0.001)$, followed by EROA (OR was $1.85 ; p<0.002)$ and vena contracta, measured preoperatively (OR 57.28; $p=0.001$ ). None of the non-echocardiographic factors had a significant relation with the recurrence of MR in the follow-up.
Tab. II. Systolic and diastolic sphericity indexes of the left ventricle (pre- and postoperatively)

\begin{tabular}{lccc} 
& Preoperatively & Follow-up & $\begin{array}{c}\text { Significance } \\
\text { level } P\end{array}$ \\
4ch diastolic SI bas & 0.59 & 0.57 & $<0.001$ \\
\hline 4ch systolic SI bas & 0.55 & 0.53 & $<0.05$ \\
\hline 4ch diastolic SI med & 0.62 & 0.60 & $<0.05$ \\
\hline 4ch systolic SI med & 0.55 & 0.54 & $<0.05$ \\
\hline 2ch diastolic SI bas & 0.62 & 0.60 & $<0.01$ \\
\hline 2ch systolic SI bas & 0.54 & 0.53 & $<0.01$ \\
\hline 2ch diastolic SI med & 0.59 & 0.57 & $<0.01$ \\
\hline 2ch systolic SI med & 0.52 & 0.52 & NS \\
\hline
\end{tabular}

4ch - four chamber view; 2ch - two chamber view; SI - sphericity index; bas - at the level of left ventricular basal segments; med - at the level of left ventricular medial segments

Tab. IV. Univariate analysis of clinical risk factors of recurrent mitral regurgitation

\begin{tabular}{lccc} 
Variable & OR & $95 \% \mathrm{Cl}$ & $\mathrm{P}$ \\
age & 0.94 & $0.87-1.01$ & $\mathrm{NS}$ \\
\hline gender & 1.01 & $0.33-3.0$ & $\mathrm{NS}$ \\
\hline $\mathrm{BMI}$ & 0.97 & $0.82-1.1$ & $\mathrm{NS}$ \\
\hline $\mathrm{BSA}$ & 0.09 & $0.005-1.39$ & $\mathrm{NS}$ \\
\hline EuroSCORE & 1.03 & $0.84-1.25$ & $\mathrm{NS}$ \\
\hline type of MR by Carpentier & 1.01 & $0.37-2.7$ & $\mathrm{NS}$ \\
classification & 4.09 & $1.4-11.95$ & 0.009 \\
\hline complex MV annuloplasty & 1.04 & $0.41-2.61$ & $\mathrm{NS}$ \\
\hline type of ring implanted & 0.94 & $0.66-1.35$ & $\mathrm{NS}$ \\
\hline ring size & 8.77 & $0.7-105$ & $\mathrm{NS}$ \\
\hline reoperation & 2.1 & $0.62-7.01$ & $\mathrm{NS}$ \\
\hline IABP & 0.63 & $0.19-2.07$ & $\mathrm{NS}$ \\
\hline prior MI & 1.7 & $0.61-4.52$ & $\mathrm{NS}$ \\
\hline diabetes & 0.66 & $0.22-1.9$ & $\mathrm{NS}$ \\
\hline arterial hypertension & & & \\
\hline
\end{tabular}

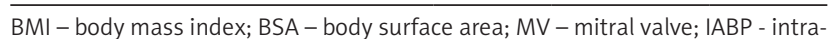
aortic counterpulsation balloon pump; MI - myocardial infarction

The multivariate analysis showed that, among the analyzed factors, only the coaptation length measured postoperatively was capable of independently predicting the recurrence of MR in long-term observation (OR 0.01; $\mathrm{Cl}$ : $0.00-0.42 ; p=0.001)$. The ROC analysis showed that the cut-off value of $0.62 \mathrm{~cm}$ for coaptation length is characterized by $94 \%$ sensitivity and $85 \%$ specificity with regard to predicting MR recurrence. The independent risk factors of the multivariate logistic regression analysis and our model of risk stratification of MR recurrence are presented in Fig. 2 and Table V.

\section{Discussion}

The rate of recurrent MR in the studied cohort of patients was relatively low. The literature reports that severe MR may occur in up to $30 \%$ of patients after mitral annuloplasty [10]. Recurrence of MR is associated with 
Tab. V. Model of risk stratification for MR recurrence

\begin{tabular}{ccccc}
$\begin{array}{c}\text { Post-op length of } \\
\text { coaptation } \leq 6.0 \mathrm{~mm}\end{array}$ & Severe MR pre-op & $\mathrm{EF} \leq 35 \%$ pre-op & BSA $\leq 1.9$ pre-op & $\begin{array}{c}\text { Risk of MR } \\
\text { recurrence (\%) }\end{array}$ \\
\hline$\beta-2.37$ & $\beta-1.94$ & $\beta-1.27$ & $\beta-1.68$ & 84.33 \\
\hline+ & + & + & + & 50.13 \\
\hline+ & + & + & + & 60.08 \\
\hline+ & + & + & + & 43.60 \\
\hline+ & - & & &
\end{tabular}

the operational technique employed, the surgeon's skill, and the progression of remodeling. Intraoperative assessment of surgical results can also play an important role. Transesophageal echocardiography routinely performed during the operation can adequately distinguish between successful and unsuccessful annuloplasty; such an approach is a standard in our center. The rate of unsuccessful mitral annuloplasty is reported as approximately $20 \%$ [10]. Unfortunately, our data are lacking information regarding the percentage of unsuccessful annuloplasty procedures. On the other hand, there are no unique criteria of unsuccessful MV repair. To the knowledge of the authors, there are no published data regarding the intraoperative, quantitative, and complex assessment of MV repair results, so echocardiographers use different criteria depending on their own preference.

The results of our study demonstrate that detailed echocardiographic examination can identify the patients who are likely to develop recurrent MR after undersized ring implantation. The EROA, vena contracta of the regurgitant jet, and LV systolic sphericity index at the level of medial segments were found to be the strongest predictors. None of the clinical or procedure-related factors had an influence on MR recurrence in the studied population, even though, in the literature, the impact of procedure-related factors and echocardiographic assessment was highlighted as an independent risk factor from the etiology of MV insufficiency [11].

Several studies have emphasized the role of echocardiography in the prediction of MR recurrence after mitral annuloplasty. Calafiore and colleagues found that the coaptation depth of more than $11 \mathrm{~mm}$ was associated with an increased risk of recurrent MR in patients with dilated cardiomyopathy [12]. In a more recent study, Kongsaerepong et al. demonstrated in a group of patients with ischemic $M R$ that the results of mitral surgery are influenced not only by tethering height, but also by mitral annular dimension and MR grade [10]. The annular dimension of $\geq 3.7 \mathrm{~cm}$ in TEE, with a tenting area of $\geq 1.6 \mathrm{~cm}^{2}$ in long axis view and MR grade $>3.5$, was associated with the failure of mitral annuloplasty in half of the patients during follow-up. Both the coaptation depth (tethering height) and tenting area reflect left ventricular remodeling resulting in mitral leaflet tethering. Our study did not confirm the predictive role of coaptation depth. However, these parameters have a burden of error, due to the difficulties presented by their measurement. Various results can be achieved depend-

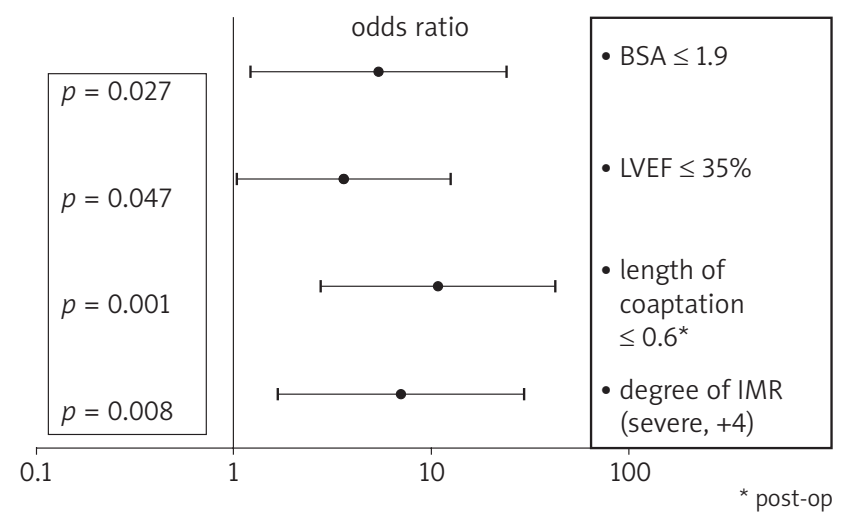

Fig. 2. Independent risk factors of multivariate logistic regression analysis

ing on the annular plane estimation and on the quality of the echocardiographic view. Moreover, our study included patients with the mechanism of MR classified as Carpentier types I and IIIB, which dramatically differ in terms of the expected measurement results of the discussed parameters. Thus, our study does not aim to devalue the importance of coaptation depth or tenting area, but rather to show that the use of these parameters is less universal than that of other parameters.

We found that coaptation length assessed within days after operation was the strongest predictor of $M V$ regurgitation recurrence. This parameter can be assumed to be the same as the measurement obtained directly at the operation theatre. Approximately $40 \%$ of patients with the postoperative coaptation length of $\leq 6.7 \mathrm{~mm}$ had severe $M R$ revealed by the follow-up echocardiographic examination. Similarly, the Leiden University study aimed to achieve the coaptation length of at least $8 \mathrm{~mm}$ as the target of restrictive ring implantation, as this value was associated with very low incidence of MR recurrence - $2.3 \%$ [13].

The reduction of coaptation length reflects the remodeling of the left ventricle caused by ischemia. It can lead to either mitral annulus dilatation or papillary muscle displacement. The key role of ventricular remodeling was also considered as a risk factor of recurrent MR after undersized mitral ring implantation. Progressive postoperative remodeling, including further papillary displacement, may potentially be responsible for the failure of restrictive annuloplasty $[8,14]$. Our study did not reveal any significant changes in LV dimensions and volumes, which called into question the feasibility of reverse LV remodeling after the correction 
of mitral insufficiency. However, the mean follow-up in our study was relatively short, which is particularly important in view of the Bax et al. report [15]. Its authors demonstrated that reverse remodeling of the LV is a gradual and timedependent process, by observing the operated patients for a period of 1.5 years.

The reverse remodeling of the LV in our study was reflected in the significantly decreased sphericity indexes. According to Di Donato, the sphericity index is even more valuable than LV dimensions and volumes. It significantly correlates with the degree of MR and, conversely, does not increase even in large ventricles without MR [16].

\section{Conclusions}

This study showed that the recurrence of MR after undersized mitral ring implantation is low. The measure of coaptation length was found to be superior to other echocardiographic parameters in the prediction of MR recurrence after restrictive annuloplasty.

\section{Study limitations}

This study is lacking data on unsuccessful undersized ring implantation. The analysis was focused on the mechanistic implications of LV remodeling as a causative factor of functional MR, whereas the pathophysiology of MR can also be explained by the LV contraction dyssynchrony. As indicated by the conducted analysis, the primary practical aspect of this study concerns the reliance on intraoperative transesophageal measurements of coaptation length rather than on postoperative assessment. Our assumption that the results of intra- and postoperative results are similar should be verified.

\section{References}

1. Agricola E, Oppizzi M, Pisani M, Meris A, Maisano F, Margonato A. Ischemic mitral regurgitation: mechanisms and echocardiographic classification. Eur J Echocardiogr 2008; 9: 207-221.

2. Hickey MS, Smith LR, Muhlbaier LH, Harrell FE Jr, Reves JG, Hinohara T, Califf RM, Pryor DB, Rankin JS. Current prognosis of ischemic mitral regurgitation: implications for future management. Circulation 1988; 78 (Suppl 1): 151-159.
3. Lamas GA, Mitchell GF, Flaker GC, Smith SC Jr, Gersh BJ, Basta L, Moyé L, Braunwald E, Pfeffer MA. Clinical significance of mitral regurgitation after acute myocardial infarction. Survival and Ventricular Enlargement Investigators. Circulation 1997; 96: 827-833.

4. Okura H, Takada Y, Kubo T, Asawa K, Taguchi H, Toda I, Yoshiyama M, Yoshikawa J, Yoshida K. Functional mitral regurgitation predicts prognosis independent of left ventricular systolic and diastolic indices in patients with ischemic heart disease. J Am Soc Echocardiogr 2008; 21: 355-360.

5. Kim YH, Czer LS, Soukiasian HJ, De Robertis M, Magliato KE, Blanche C, Raissi SS, Mirocha J, Siegel RJ, Kass RM, Trento A. Ischemic mitral regurgitation: revascularization alone versus revascularization and mitral valve repair. Ann Thorac Surg 2005; 79: 1895-1901.

6. Shuhaiber J, Anderson RJ. Meta-analysis of clinical outcomes following surgical mitral valve repair or replacement. Eur J Cardiothorac Surg 2007; 31: 267-275.

7. Reul RM, Cohn LH. Mitral valve reconstruction for mitral insufficiency. Prog Cardiovasc Dis 1997; 39: 567-599.

8. Tahta SA, Oury JH, Maxwell JM, Hiro SP, Duran CM. Outcome after mitral valve repair for functional ischemic mitral regurgitation. J Heart Valve Dis 2002; 11: 11-19.

9. McGee EC, Gillinov AM, Blackstone EH, Rajeswaran J, Cohen G, Najam F, Shiota T, Sabik JF, Lytle BW, McCarthy PM, Cosgrove DM. Recurrent mitral regurgitation after annuloplasty for functional ischemic mitral regurgitation. J Thorac Cardiovasc Surg 2004; 128: 916-924.

10. Kongsaerepong V, Shiota M, Gillinov AM, Song JM, Fukuda S, McCarthy PM, Williams T, Savage R, Daimon M, Thomas JD, Shiota T. Echocardiographic predictors of successful versus unsuccessful mitral valve repair in ischemic mitral regurgitagtion. Am J Cardiol 2006; 98: 504-508.

11. Gillinov AM, Cosgrove DM, Lytle BW, Taylor PC, Stewart RW, McCarthy PM, Smedira NG, Muehrcke DD, Apperson-Hansen C, Loop FD. Reoperation for failure of mitral valve repair. J Thorac Cardiovasc Surg 1997; 113: 467-473.

12. Calafiore AM, Gallina S, Di Mauro M, Gaeta F, lacò AL, D’Alessandro S, Mazzei V, Di Giammarco G. Mitral valve procedure in dilated cardiomyopathy: repair or replacement? Ann Thorac Surg 2001; 71: 1146-1153.

13. Braun J, Bax JJ, Versteegh MI, Voigt PG, Holman ER, Klautz RJ, Boersma E, Dion RA. Preoperative left ventricular dimensions predict reverse remodeling following restrictive mitral annuloplasty in ischemic mitral regurgitation. Eur J Cardiothorac Surg 2005; 27: 847-853.

14. Hung J, Papakostas L, Tahta SA, Hardy BG, Bollen BA, Duran CM, Levine RA. Mechanism of recurrent mitral regurgitation after annuloplasty: continued LV remodeling as a moving target. Circulation 2004; 110: 1185-1190.

15. Bax JJ, Braun J, Somer ST, Klautz R, Holman ER, Versteegh MI, Boersma E, Schalij MJ, van der Wall EE, Dion RA. Restrictive annuloplasty and coronary revascularization in ischemic mitral regurgitation results in reverse left ventricular remodeling. Circulation 2004; 110 (11 Suppl 1): ॥103-॥108.

16. Di Donato M, Dabic P, Castelvecchio S, Santambrogio C, Brankovic J, Collarini L, Joussef T, Frigiola A, Buckberg G, Menicanti L; RESTORE Group. Left ventricular geometry in normal and post-anterior myocardial infarction patients: sphericity index and ,new' conicity index comparisons. Eur J Cardiothorac Surg 2006; 29 Suppl 1: S225-S230. 